\title{
Neuropeptide Y Receptor Type 5
}

National Cancer Institute

\section{Source}

National Cancer Institute. Neuropeptide Y Receptor Type 5. NCI Thesaurus. Code

C105413.

Neuropeptide $Y$ receptor type 5 ( $445 \mathrm{aa}, \sim 51 \mathrm{kDa}$ ) is encoded by the human NPY5R gene.

This protein is involved in diverse physiological functions as a receptor for neuropeptide Y. 